САВЧАК Ірина - кандидат педагогічних наук, дочент кафедри іноземних мов і перекладу, Прикарпатський національний університет імені Василя Стефаника, вул. Шевченка 57, м. ІваноФранківськ, 76000, Украӥна

ORCID: https://orcid.org/0000-0003-0326-5779

DOI: https://doi.org/10.24919/2413-2039.13/45.9

Бібліографічний опис статті: Савчак, I. (2021) Розвиток мотивації студентів до вивчення іноземної мови в умовах дистанційного навчання. Людинознавчі студії. Серія «Педагогіка», № 13(45), 64-70, doi: https://doi.org/10.24919/2413-2039.13/45.9

\title{
РОЗВИТОК МОТИВАЦІЇ СТУДЕНТІВ ДО ВИВЧЕННЯ ІНОЗЕМНОЇ МОВИ В УМОВАХ ДИСТАНЦІЙНОГО НАВЧАННЯ
}

\begin{abstract}
Анотація. Статтю присвячено визначенню основних шляхів підвищення мотивації студентів до вивчення іноземної мови за допомогою дистаниійних технологій. Світова пандемія COVID-19 повністю змінила усталений спосіб життя суспільства. Освіта - одна зі сфер, яка зазнала глобальних змін $i$, здавалось би, основним завданням було впровадження інноваційних технологій, які допоможуть налагодити освітній проиес, але постало інше питання - забезпечення мотивації студентів в умовах дистанційного навчання з метою досягнення якісного результату. Питання розвитку мотивації студентів належсть сьогодні до найбільш актуальних, адже мотивація - це спонукальна сила, яка впливає на формування поведінки особистості, спрямовує ї̈ діяльність і дї̈ на мотиваційні об'єкти, контролює реалізацію намірів, сприяє вибору нових технік і стратегій для реалізації мотивів. У статті відзначено важливість мотивації у вивченні іноземної мови в умовах дистанційного навчання за допомогою сучасних інформаційних технологій. Визначено поняття «дистаниійне навчання», щзо передбачає інтеграцію інформаційних і педагогічних технологій, щзо забезпечують інтерактивність взаємодіі педагога і студента, а також продуктивність навчального процесу. Визначено, що ключовими у вивченні мов є внутрішня $і$ зовнішня мотивації. Внутрішня мотивація полягає у виконанні завдання, бо цее приносить задоволення, а не заради доброї чи поганої оиінки. Зовнішня ж мотивачія викликана зовнішніми чинниками, такими як задоволення очікувань викладача чи хороша оцінка. Проаналізовано сучасні інформаційні технологї: програми, додатки, застосунки, які використовуються у навчальному процесі для підвищення рівня мотиваиії студентів у вивченні іноземних мов. Зазначено важливість ролі викладача в иьому прочесі, в його вмінні організувати навчальний прочес, створити позитивну доброзичливу атмосферу спілкування начального середовища. Виокремлено перелік програм, які можна використовувати на заняттях з метою підвищення рівня мотивації студентів до навчання мови.
\end{abstract}

Ключові слова: дистанційне навчання, внутрішня мотивація, зовнішня мотивачія, інформаційні технології.

SAVCHAK Iryna - PhD in Pedagogical Sciences, Associate Professor at the Foreign Languages and Translation Department, Vasyl Stefanyk Precarpathian National University, T. Shevchenko Str., 57, IvanoFrankivsk, 76000, Ukraine

ORCID: https://orcid.org/0000-0003-0326-5779

DOI: https://doi.org/10.24919/2413-2039.13/45.9

To cite this article: Savchak, I. (2021). Rozvytok motyvatsii studentiv do vyvchennia snozemnoii movy $\mathrm{v}$ umovakh dyctantsiinoho navchannia [Development of students' motivation to foreign language studying in the context of distance learning]. Human Studies. Series of Pedagogy, № 13(45), 64-70, doi: https:// doi.org/10.24919/2413-2039.13/45.9 


\section{DEVELOPMENT OF STUDENTS' MOTIVATION TO FOREIGN LANGUAGE STUDYING IN THE CONTEXT OF DISTANCE LEARNING}

Summary. The article deals with the main ways to increase the motivation of students to learn a foreign language with the help of remote technologies. The global Covid19 pandemic has completely changed the established way of life of society. Education is one of the areas that has undergone global changes. And the main task was just to introduce innovative technologies that would help to establish the educational process, but the issue of students' motivation in distance learning appeared. The issue of developing students' motivation is of primary importance today, because motivation is a force that influences the formation of individual behavior, directs its activities and actions to motivational objects, controls the implementation of intentions, promotes the choice of new techniques and strategies for motivation. The article notes the importance of motivation in learning a foreign language in the context of distance learning with the help of modern information technologies. The concept of "distance learning" has been defined, which provides for the integration of information and pedagogical technologies that ensure the interaction of a teacher and a student, as well as the productivity of the educational process. Internal and external motivation has been determined to be the key in the study of languages. Internal motivation brings you satisfaction while completing the assignment. External motivation is caused by external factors, such as meeting the teacher's expectations or a good grade. Modern information technologies have been analyzed: programs and applications used in the educational process to increase the level of motivation of students in learning foreign languages. The importance of a teacher in this process has been indicated as well as their ability to organize the educational process, to create a positive and friendly atmosphere of communication in the educational environment. The list of applications that can be used in the class in order to increase the level of students' motivation to foreign language learning has been singled out.

Key words: distance learning, internal motivation, external motivation, information technologies.

\section{Вступ}

Запровадження карантину в березні 2020 року повністю змінило усталений спосіб життя суспільства. Освіта - одна зі сфер, яка зазнала глобальних змін і повинна була швидко адаптуватися до нових умов та якісно організувати навчання. Здавалось би, основним завданням було впровадження інноваційних технологій, які допоможуть налагодити освітній процес, але постало інше питання забезпечення мотивації студентів під час дистанційного навчання з метою досягнення якісного результату. Питання мотивації студентів належить сьогодні до найбільш актуальних, адже мотивація - це спонукальна сила, яка впливає на формування поведінки особистості, спрямовує ii діяльність та дії на мотиваційні об'єкти, контролює реалізацію намірів, сприяє вибору нових технік і стратегій для реалізації мотивів.

Не підлягає сумніву той факт, що рушійною силою поведінки людини, зокрема навчання, є мотивація. Вона пронизує всі основні віхи освіти людини й забезпечує високу результативність навчання. У дистанційному навчанні мотиваційні фактори стають ключовими, оскільки їх відсутність ставить під сумнів результат навчання. Тому особливо важливим сьогодні є питання про шляхи підвищення мотивації освітньо-професійної діяльності в контексті дистанційної освіти.

Актуальність дослідження полягає в тому, що дистанційна освіта впевнено займає особливе місце серед форм освіти і невпинно продовжує розвиватися. Саме дистанційне навчання $є$ тією продуктивною формою, в якій використовуються традиційні та інноваційні методи, засоби і форми навчання, засновані на комп'ютерних і телекомунікаційних технологіях. Натепер дистанційні технології залишаються незамінними, оскільки є єдиним джерелом отримання освітніх послуг для більшості студентів. У такому випадку важливим для закладів вищої освіти загалом та викладачів зокрема $є$ саме побудова логічної, цілком обгрунтованої та прийнятної системи мотивів і спонукань до використання дистанційної форми навчання.

\section{Аналіз останніх досліджень}

Питання підвищення мотивації до навчання викликає інтерес як в іноземних, так і у вітчизняних науковців. Провідні дослідження 3 цього напряму оприлюднили автори: С. Бобровицька, Л. Божович, Н. Волкова, О. Гилюн, А. Гебос, С. Ільїн, В. Кикоть, В. Леонтьєв, А. Маркова, М. Матюхіна, 
В. Полянська, А. Реан, О. Тарнопольський, В. Якунін та ін. Важливість формування мотивації до вивчення іноземної мови підкреслюється такими науковцями, як R. Gardner, G. Crookes, J. Harmer, W. Lambert, R. Schmidt, Є. Пасов, П. Гуревич.

Проте дослідження мотивації до вивчення іноземної мови в умовах дистанційного навчання потребує ширшого обговорення науковцями, особливо в контексті останніх подій, викликаних пандемією COVID-19.

\section{Мета статті}

Мета статті полягає у визначенні основних шляхів підвищення мотивації студентів до вивчення іноземної мови за допомогою дистанційних технологій.

\section{Виклад основного матеріалу}

Питання підвищення мотивації в умовах дистанційного навчання потребує насамперед розуміння поняття «дистанційне навчання». Виділяють два підходи до тлумачення цього терміна. За першим підходом, дистанційне навчання розглядають як процес обміну інформацією між педагогами й тими, хто навчається, за допомогою електронних мереж чи інших засобів телекомунікацій. Студент при цьому одержує навчальну інформацію і завдання щодо іiї засвоєння, а потім результати своєї самостійної роботи надсилає педагогу, який оцінює якість і рівень засвоєння матеріалу. При цьому особиста діяльність студента зі здобуття знань майже не організовується. Другий підхід передбачає інтеграцію інформаційних і педагогічних технологій, що забезпечують інтерактивність взаємодії педагога і студента, а також продуктивність навчального процесу. Тобто особистісна продуктивна діяльність того, хто навчається, вибудовується за допомогою сучасних засобів телекомунікацій і $є$ головним елементом дистанційного навчання. Таким чином, дистанційне навчання припускає одержання освітніх послуг на відстані, в основному без відвідування закладу вищої освіти, за допомогою новітніх комп'ютерних і комунікаційних технологій і являє собою універсальну, синтетичну, інтегральну, гуманістичну форму навчання, що створює умови для студентів та адаптована до базового рівня знань і контрольних цілей студентів (Колос, 2020). Вважаємо, що саме така інтерпретація $є$ найбільш прийнятною і такою, що відповідає сучасним реаліям освітньої діяльності.

Як уже зазначалось, безперечним чинником успішності навчання в цілому і вивчення іноземної мови зокрема є мотивація. Вона активізує поведінку особистості, спрямовує діяльність студентів на конкретні цілі; розвиває соціально важливі здібності та якості, покращує результативність і формує почуття дисциплінованості.

Поняття мотивації трактується по-різному. Так, дослідники визначають мотивацію і як один конкретний мотив, і як єдину систему мотивів, і як особливу сферу, що включає в себе потреби, цілі, мотиви, інтереси в їх складному сплетінні. Структура мотиву як основи дії або вчинку -багатокомпонентна, в ній найчастіше знаходять відображення кілька причин і цілей.

Американський учений Р. Гарднер (2001) вважає, що «мовні навчальні стратегії, ймовірно, не спрацюють, якщо індивід не мотивований на вивчення мови» (с. 2-4), і визначає мотивацію до вивчення іноземної мови як «міру, до якої людина працює або прагне вивчити мову через бажання це зробити та задоволення від цієї діяльності» (Гарднер, 2001, с. 10). С. Гончаренко вважає, що мотивація - це «система мотивів, або стимулів, яка спонукає людину до конкретних форм діяльності або поведінки» (Гончаренко, 1997, c. 217).

На нашу думку, мотивація є сукупністю мотивів, які спонукають людину до певних дій з метою отримання бажаного результату. Тобто мотив є складовою частиною поняття «мотивація» i тією рушійною силою, яка здатна активізувати та спонукати людину до певних дій.

Розрізняють мотивацію зовнішню та внутрішню, остання у свою чергу ділиться на перспективну та процесуальну (Міхненко, 2010). Зовнішня мотивація розвивається, наприклад, через спонукання людини вчитися і не сприяє досягненню високих результатів навчання. Тим більше не варто на неї розраховувати в навчанні вже фактично дорослих людей, до яких можна віднести і студентів ЗВО. Тобто ключовою в нашому випадку $\epsilon$ внутрішня мотивація, в якій стимули до навчання породжуються саме тим, хто навчається, і діяльність починає виконуватися заради ii власного змісту. Така висока позитивна внутрішня мотивація у вивченні іноземних мов виникає в тому випадку, коли процес оволодіння мовою має для тих, хто навчається, особистісну значущість, яка у свою чергу є результатом формування перспективної та процесуальної мотивацій. 
О. Тарнопольський (2008) вказує на те, що перспективну внутрішню мотивацію мають практично всі студенти, усвідомлюючи значення знання англійської мови для їхнього життя та кар'єри. Однак люди відволікаються від таких майбутніх благ сьогоденними проблемами, розвагами або просто лінощами. Вплив процесуальної мотивації зовсім інший, адже вона пов'язана із задоволенням від самого процесу діяльності, тому, коли вдається сформувати іiї (процесуальну мотивацію) у процесі вивчення мови, успіх навчання $\epsilon$ в значній мірі гарантованим.

Особливою популярністю користується теорія «цілеспрямованої мотивації», компонентами якої $\epsilon$ : «внутрішня» мотивація (core motivation) - почуття, бажання, зусилля; орієнтація на навчання та ставлення до навчальної ситуації. Так Р. Гарднер i У. Ламберт (1972) визначають дві орієнтації у вивченні мови - інструментальну (є результатом зовнішніх чинників і пов'язана з бажанням того, хто навчається, вивчити мову задля досягнення такої мети, наприклад, як складання іспиту чи кар'єрний ріст) та інтегральну (виходить із внутрішнього мотиву людини і пов'язана з бажанням того, хто навчається, вивчити мову через високе позитивне особистісне ставлення до цієї мови, народу, який нею спілкується, культурі тощо). Варто зауважити, що студент у більшій чи меншій мірі поєднує ці два типи мотивації, що формує макромотивацію, тобто в нашому контексті - макромотивацію до вивчення іноземної мови засобами дистанційного навчання.

Інколи володіючи досить високим рівнем інструментальної та інтегративної мотивації, особа залишається демотивованою нудною парою чи неприємним навчальним середовищем. I навпаки, цікава навчальна діяльність сприяє розвитку мотивації до вивчення мови, навіть якщо немає наявних бажань чи потреб це робити. Тобто існує також і мікромотивація, яка включає відчуття і потреби студента в процесі самого навчання. Мікромотивація охоплює біологічні чинники, зовнішню і внутрішню мотивацію.

Найпростішою формою мотивації є біологічні мотиви, вони формуються під впливом наших психічних чи фізичних потреб, тобто це те, що спонукає нас їсти, відпочивати, спати, гарно виглядати, дружити.

Внутрішня і зовнішня мотивації $\epsilon$ ефективнішими у вивченні мови. Так, внутрішня мотивація вважається найкращою формою мотивації і полягає в тому, що ти виконуєш певне завдання, бо це приносить задоволення і радість, а не заради доброї чи поганої оцінки. Зовнішня мотивація викликана зовнішніми чинниками, такими як задоволення очікувань викладача чи хороша оцінка. Зазвичай вона недовготривала i минає, як тільки завдання виконано.

Г. Крукс і Р. Шмідт (1991) визначають чотири основних рівні мотивації у вивченні мови: мікрорівень, рівень роботи в класі, рівень навчальної програми та рівень, пов'язаний iз зовнішніми факторами. Вони застосовують принципи «очікуваності результату» та самостійності в поясненні теорії мотивації в навчанні (с. 469-512). Дж. Келер (1983) вводить чотири умови успішної вмотивованої діяльності: інтерес (до теми та діяльності), актуальність, очікування (успіху та контролю), задоволення.

3. Дернеї (2010) аналізує мотивацію навчання в межах трьох рівнів, які включають у себе цілий ряд факторів мотивації, а саме: 1) рівень мови (культура, суспільство, практична важливість мови та оволодіння нею); 2) рівень студента (самоефективність, упевненість у собі, орієнтація на результат тощо); 3) рівень навчальної ситуації (вплив особистості викладача, його поведінки, стилю викладання, вплив навчальних програм, матеріалів, методів і прийомів навчання та вплив групової динаміки).

Дж. Келлер (1983) виокремлює чотири умови успішної вмотивованої діяльності: 1) інтерес до теми та діяльності, 2) актуальність, 3) очікування успіху та контролю, 4) задоволення (с. 383-434).

О. Знанецька і В. Райлянова (2012) розробили свою класифікацію внутрішньої мотивації людини стосовно навчання іноземної мови. Вони виділяють комунікативну мотивацію, яка базується на потребі людини в спілкуванні іноземною мовою з колегами, друзями, вміти читати 3 метою розширення кругогляду, як із професійною ціллю, так і для власного задоволення, писати на іноземній мові друзям, колегам. Лінгвопізнавальна мотивація полягає в позитивному ставленні студентів до самої «мовної матерії», до вивчення основних якостей мовних знаків. Інструментальна мотивація випливає з позитивного ставлення студентів до певних видів роботи.

Про важливість викладача у формуванні мотивації до вивчення іноземної мови нагадує I. Зимня. Так, на іiї думку, «розкутість, 
відсутність страху, радісне ставлення до вчителя, навчання, прагнення до доброзичливого взаєморозуміння в групі - результат вибраного вчителем правильного стилю спілкування» (Зимня, 2004, с. 158). Завдання викладача полягає у використанні таких методів навчання, які сприятимуть розвиткові мотивації до вивчення іноземної мови засобами дистанційного навчання.

То що ж робити викладачеві, щоб підвищити рівень мотивації вивчення іноземної мови засобами дистанційного навчання?

Зарубіжні дослідники (Деннен \& Бонк, 2006, с. 64) визначили 10 мотиваційних елементів, необхідних для розвитку і підтримки мотивації дистанційного навчання. До них належать: мікроклімат у групі, оточення; зворотній зв'язок з викладачем; участь, залучення до різних форм діяльності; важливість діяльності для самого студента; можливість вибору; різноманітність завдань навчальної діяльності; зацікавленість; інтенсивність навчання; взаємодія 3 іншими студентами; орієнтація на мету. Вони є актуальними як для дистанційного навчання, так і для живого. Викладачам слід звертати увагу на ці ключові моменти, плануючи заняття чи цілі курси.

Що ж до технологій в освіті, то вони стали невід'ємною частиною навчального процесу. Використання різноманітних застосунків допомагає не тільки вчити мову, але й сприяє розвитку творчих здібностей, чим підвищує інтерес до навчання. Натепер розроблено величезну кількість програм, додатків, застосунків для забезпечення дистанційного навчання, для створення інформативного, цікавого, пізнавального, творчого середовища навчання. Кожна програма використовується 3 конкретною метою, для розвитку тих чи інших навичок та вмінь. Так, спираючись на власний досвід і досвід колег, можемо виділити такі програми для вивчення іноземних мов: для мозкового штурму корисними будуть Webspiration, Venn Diagrams, Smart Tools; у вивченні нової лексики допоможуть Word Cloud Generator i Word Processing App; збирати та аналізувати інформацію можна на Survey Monkey, Poll Everywhere; для створення мультимедійних презентації - PowToon, Prezi, Keynote; організовувати квести - WebQuest, Quizlet; дізнаватися останні новини та цікаву інформацію - Voice of America, BBC Learning English та багато інших. Окремої уваги в навчанні мови заслуговує програма Му Grammar Lab. Це універсальна розробка, яку можна використовувати як в очному навчанні, так і в дистанційному. Її перевагою $\epsilon$ те, що вона поєднує всі види мовленнєвої діяльності (reading, speaking, writing, listening), включає різноманітні завдання, аудіо- та відеоматеріали, а також студенти одразу можуть побачити отриману оцінку й помилки, які вони допустили під час виконання тієї чи іншої вправи. Як показує досвід, це припало до вподоби студентам i, безсумнівно, підвищує їхній рівень мотивації до вивчення мов. Варто зауважити, що застосування сучасних інформаційних технологій сприяє пізнавальній діяльності студентів, посилює зацікавленість до процесу навчання.

Вагомим чинником підвищення мотивації до навчання іноземної мови є спілкування 3 носіями мови. Працюючи онлайн, можна легко долучити гостя 3 будь-якої частини світу, що $\epsilon$, безперечно, великою перевагою. Саме така діяльність покликана розвивати зовнішню мотивацію: щоб зрозуміти співрозмовника, щоб спілкуватися з ним, ти повинен знати мову. Зазвичай варто запрошувати до розмови людину, яка прямо пов'язана 3 майбутньою професійною діяльністю студентів, адже це буде додатковим стимулом для вивчення мови.

Ще однією передумовою підвищення навчальної мотивації $є$ чітке розуміння кінцевої мети навчання: «чого я досягну, яким буде результат моєї діяльності»? Тому завдання викладача - ще на першому занятті чітко окреслити завдання, мету, структуру курсу, вимоги, які висуваються до студента, так само як і обов'язки викладача. Толерантність, взаємовідповідальність у системі викладач-студент, студент-студент, студент-викладач сприятиме налагодженню гармонійних відносин, створить доброзичливий мікроклімат у групі. Важливою складовою частиною мотивації студента $\epsilon$ відчуття власного розвитку, тому оцінка результатів навчання, похвала, підтримка, постійний фідбек підвищать його упевненість у власних силах і в тому, що він успішно завершить курс. Не можемо не погодитися 3 науковцями в питанні надання автономії студентам під час вибору завдань, партнерів для їх виконання, жорстких часових обмежень, адже розуміємо, що саме це формує відповідальність за прийняті рішення, вчить самостійності, розвиває відчуття власної значущості. Але найважливішим чинником підвищення мотивації студентів до вивчення іноземної мови в умовах дистанційного навчання 
$є$ особистість викладача, його ентузіазм, його натхнення, його любов до власної справи.

\section{Висновки}

Підсумовуючи вищесказане, варто зазначити, що мотивація є важливим чинником успішності навчального процесу. Студент повинен насамперед усвідомити важливість вивчення іноземної мови для себе, для своєї майбутньої професійної діяльності, незважаючи на те, очне це чи дистанційне навчання, тобто сформувати чітку внутрішню мотивацію. Завдання ж викладача - організувати навчальний процес таким чином, щоб студенти мали бажання відвідувати заняття, розуміли необхідність володіння іноземною мовою в сучасному світі. У контексті дистанційного навчання важливі саме сучасні інформаційні технології, програми, додатки, які здатні змінити ставлення студентів до навчання, перетворити його з нудної одноманітної діяльності в захоплюючий процес постійного розвитку і вдосконалення себе і своїх знань. Сьогодні можна легко підібрати програми, які зроблять навчальний процес більш інформативним, пізнавальним, професійно-спрямованим, творчим та цікавим, що, безумовно, підвищить рівень мотивації студентів до вивчення іноземним мов, особливо під час дистанційного навчання.

\section{ЛІТЕРАТУРА}

1. Гончаренко С.У. Український педагогічний словник. Київ : Либідь, 1997. 376 с.

2. Зимняя И.А. Педагогическая психология. Москва : Логос, 2004. 384 с.

3. Знанецька О.М. Проблеми мотивації навчання у вищій школі. Вісник Запорізького національного університету. 2012. Вип. 2 (18). С. 87-91.

4. Колос Ю.З. Мотивація навчально-пізнавальної діяльності студентів під час дистанційного навчання іноземних мов. Гуманітарний вісник національного університету імені Юрія Кондратюка. 2020. Вип. 1-2 (7). С. 21-28.

5. Міхненко Г.Е. Мотивація як рушійна сила процесу оволодіння іноземною мовою студентами немовних вузів. Збірник матеріалів конференції «Край на научното развитие - 2010». София : «БялГРАД-БГ» ООД, 2010. 96 c. URL: http://www.kamts1.kpi.ua/sites/default/files/files/01_pub(11).pdf

6. Тарнопольский О.Б. Методика навчання студентів вищих навчальних закладів письма англійською мовою. Вінниця : Нова книга, 2008. 288 с.

7. Crookes G., Shmidt R. Motivation : Reopening the research agenda. Language Learning. 1991. URL: http:// nflrc.hawaii.edu/PDFs/SCHMIDT\%20Motivation\%20-\%20Reopening\%20the\%20research\%20agenda.pdf

8. Vanessa Paz Dennen, Curtis J. Bonk. We'll Leave the Light on for You: Keeping Learners Motivated in Online Courses. Flexible Learning in an Information Society. 2006. Chap. 6. P. 64-76.

9. Dornyei Z. Motivational strategies in the language classroom. Cambridge : Cambridge University Press, $2001.245 \mathrm{p}$.

10. Gardner R., Lambert W. Attitudes and motivation : Second language learning. Newbury House, 1972.

11. Gardner R.C. Language Learning Motivation: The Student, the Teacher, and the Researcher. Texas Papers in Foreign Language Education, 2001.

12. Keller J.M. Motivational Design of Instruction. Instructional Design Theories and Models: An Overview of their Current Status. NJ : Lawrence Erlbaum, 1983.

\section{REFERENCES}

1. Honcharenko S. U. (1997). Ukrayins'kyy pedahohichnyy slovnyk [Ukrainian Pedagogical Dictionary]. Kyiv: Lybid', 1997, 376p. [in Ukrainian]

2. Zimnyaya I. A. (2004) Pedagogicheskaya psikhologiya [Pedagogical Psycology] Moscow: Logos, 384 p. [in Russian].

3. Znanets'ka O. M, Raylyanova V. E. (2012). Problemy motyvatsiyi navchannya u vyshchiy shkoli [Problems of motivation to study in high school] Visnyk Zaporiz'koho natsional'noho universytetu. Vol. 2(18), P. 21-28. [in Ukrainian].

4. Kolos Yu. Z., Fedorenko Yu. P. (2020). Motyvatsiia navchalno-piznavalnoi diialnosti studentiv pid chas dystantsiinoho navchannia inozemnykh mov [Motivation of educational and cognitive activity of students during distance learning of foreign languages]. Humanitarnyi visnyk natsionalnoho universytetu imeni Yuriia Kondratiuka. Vol. 1-2(7), P. 21-28. [in Ukrainian]

5. Mikhnenko H. E. (2010). Motyvatsiia yak rushiina syla protsesu ovolodinnia inozemnoiu movoiu studentamy nemovnykh vuziv [Motivation as a driving force in the process of mastering a foreign language by students of nonlanguage universities]. Zbirnyk materialiv konferentsii “Kray na nauchnoto razvitia - 2010". Sophia. 96p. Available at: http://www.kamts1.kpi.ua/sites/default/files/files/01_pub(11).pdf. [in Ukrainian] 
6. Tarnopolskyi O. B., Kozhushko S. V. (2008). Metodyka navchannia studentiv vyshchykh navchalnykh zakladiv pysma anhliiskoiu movoiu [Methods of writing teaching of students of higher educational institutions in English]. Vinnytsia. Nova knyha. 2008. 288p. [in Ukrainian]

7. Grookes, G., \& Shmidt, R. (1991). Motivation: Reopening the research agenda. Language Learning. URL:http://nflrc.hawaii.edu/PDFs/SCHMIDT\%20Motivation\%20\%20Reopening\%20the\%20research\%20 agenda.pdf

8. Vanessa Paz Dennen, Curtis J. Bonk. We'll Leave the Light on for You: Keeping Learners Motivated in Online Courses. Flexible Learning in an Information Society. 2006. Chap. 6. P. 64-76.

9. Dörnyei Z. (2001). Motivational Strategies in the Language Classroom. Cambridge University Press.

10. Gardner, R, \& Lambert, W. (1972). Attitudes and motivation : Second language learning. Newbury House.

11. Gardner, R. C. (2001). Language Learning Motivation: the Student, the Teacher, and the Researcher. Texas Papers in Foreign Language Education.

12. Keller, J. M. (1983). Motivational Design of Instruction. Instructional Design Theories and Models: An Overview of their Current Status. NJ: Lawrence Erlbaum. 